\title{
24 Haziran Genel Seçimlerinde Ak Parti, CHP ve MHP'nin Televizyon Reklamları Üzerine Bir Değerlendirme
}

\author{
Zühal Fidan Baritci (Dr. Öğr. Üyesi) \\ Aksaray Üniversitesi İletişim Fakültesi \\ zuhal fidan@hotmail.com \\ Orcid: 0000-0002-0957-1040
}

Başvuru Tarihi: 26.12.2018

Yayına Kabul Tarihi: 18.02.2019

Yayınlanma Tarihi: 22.07.2019

DOI: 10.17680/erciyesiletisim.502981

Fidan Baritci, Z. (2019). 24 Haziran Genel Seçimlerinde Ak Parti, CHP ve MHP'nin Televizyon Reklamları Üzerine Bir Değerlendirme. Erciyes İletişim Dergisi, 6 (2), 815-826. DOI: 10.17680/ erciyesiletisim.502981

\section{Öz}

Siyasal kampanyalar seçim yarışına katılan siyasi parti ve adaylar için oldukça önemlidir. Zorlu bir seçim sürecinin sonunda iktidara sahip olmak isteyen siyasi partiler çeşitli yol ve yöntemleri kullanarak seçmen kitlelerine ulaşmaktadırlar. Siyasal reklamlar, seçmen kitleye ulaşmayı kolaylaştıracak yol ve yöntemlerin arasında yer almaktadır. Bu özelliğiyle siyasal reklamlar, siyasi partilerin tanıtılmasında kilit rol oynamaktadır. Siyasi partiler seçimlerin yönünü tayin etmede önemli işlevlere sahip olan siyasal reklamlar vasıtasıyla siyasal vaatleri ulaștırmaya çalışırlar. Seçmenleri bilgilendirmek ve etkilemek adına siyasal reklamcılıktan yararlanan siyasi partiler yine siyasal reklamcılığın imaj oluşturma gücünden de faydalanmaktadırlar. 24 Haziran 2018 'de yapılan milletvekili ve cumhurbaşkanlığ seçimlerinde partiler ve cumhurbaşkanlığı adayları siyasal reklamlardan yararlanmışlardır. Söz konusu seçim sürecinde rakiplerin bir adım ötesine geçmek ve mesajlarını hedef kitleye ulaştırmak amacıyla siyasal reklamcılıktan faydalanan Ak Parti, CHP ve MHP'nin televizyonda yayınlanan seçim reklamları bu araştırmanın konusunu oluşturmaktadır. Bu amaçla seçimlerde mecliste çoğunluğu sağlamayı amaçlayan Ak Parti, CHP ve MHP'nin siyasal reklamları içerik çözümleme yöntemi ile değerlendirilmektedir. Araștırmanın sonucunda siyasi partilerin yürüttükleri siyasal kampanyalar ve mesaj stratejilerindeki farklılıkları ortaya çıkarılmıştır. Ak Parti'nin reklamlarının diğer siyasi partilere göre sayıca fazla olduğu ve genellikle pozitif içerikli reklamların yayınlandığı sonucuna ulaşılmıştır. Ak Parti reklamlarında hâkim tema milli birlik ve beraberliktir. CHP negatif içerikli reklamlara daha fazla yer verirken, reklamlarında ekonomiden engellilere, eğitimden hak ve özgürlüklere kadar pek çok konuyu işlemiştir. MHP ise sayıca az olan reklamlarında pozitif içeriğe yer vererek milli birlik ve beraberlik vurgusu yapmıştır.

Anahtar Kelimeler: 24 Haziran Seçimleri, Siyasal Reklamcılık, Televizyon Reklamları, Negatif ve Pozitif Reklam. 


\title{
An Evaluation on Television Advertising of Ak Parti, CHP and MHP on 24th June Election
}

\author{
Zühal Fidan Baritci (Asst. Prof. Dr.) \\ Aksaray University Faculty of Communication \\ zuhal_fidan@hotmail.com \\ Orcid: 0000-0002-0957-1040
}

Date Received: 26.12 .2018

Date Accepted: 18.02.2019

Date Published: 22.07.2019

DOI: $10.17680 /$ erciyesiletisim.502981

\begin{abstract}
The political campaigns are very important for the political parties and candidates attending the election race. The political parties aiming to achieve the power at the end of a hard election period address their electorate by using different ways and methods. The political advertisements are one of these ways and methods that make easier to reach the electorate. Together with this character, the political advertisements play a key role in introducing the political parties. The political parties try to convey their promises to the voters through the political advertisements, which have important functions in determining the direction of the elections. The political parties benefiting from political advertisements in order to inform and influence the voters also benefit from the political advertisements' power of creating an image. The parties and presidential candidates benefited from the political advertisements in the parliamentary and presidential elections took place on 24th June 2018. The political TV advertisements used by Ak Parti, CHP, and MHP in order to move ahead of their rivals and to convey their messages to the target audience during the aforementioned election period constitute the subject of present study. For this purpose, the political advertisements of Ak Parti, CHP, and MHP aiming to achieve the majority in parliament are examined using the content analysis method. At the end of this research, the differences between the political campaigns of the political parties and their message strategies were revealed. It was determined that, when compared to those of other parties, the number of AK Parti's advertisements was higher and they generally incorporate positive messages. The prominent theme in the advertisements of AK Parti is national unity and solidarity. On the other hand, CHP's advertisements incorporate negative messages and focused on many subjects such as economy, disabled individuals, education, rights, and freedoms. In its limited number of advertisements, MHP emphasized the national unity and solidarity by including positive contents in its advertisements.
\end{abstract}

Keywords: 24th June Elections, Political Advertising, TV Advertisements, Negative and Positive Advertisements. 


\section{Giriş}

Siyasal partiler ve adaylar seçmenleri ikna etmek için çeşitli siyasal iletişim faaliyetlerinde bulunmaktadırlar. Bu siyasal iletişim faaliyetlerinden biri olan siyasal reklamlar seçim sürecinde kampanyaların seçmenlere anlatılması hususunda oldukça etkilidir. Siyasal reklam, yüksek bütçeye ihtiyaç duyan, profesyonel bir yardım gerektiren ve kampanya mesajlarını seçmene ulaştıran önemli bir araçtır (Uztuğ, 2004, 315). Nitekim siyasal reklamlar liderleri, adayları, siyasi partileri ve parti programlarını tanıtma firsatı yakalamanın ve seçim yarışında bir adım daha öne çlkabilmenin formülüdür. Böylece seçmenin reklamda yer alan siyasi partiye ya da adaya oy vermesi hususunda ikna edilme süreci işlemeye başlar. Demokrasinin hâkim olması seçim dönemlerinde siyasi parti ve adaylara eşit şekilde seçim yarışına katılma fırsatı sunmaktadır. Ancak siyasi parti bütçeleri eşit olmadığı için her siyasi parti kendi bütçesi ölçüsünde bir çalışma yapma hazırlığındadır.

Seçim dönemlerinde reklam kampanyalarını seçmenlere ulaştırmada çeşitli kitle iletişim araçlarından yararlanan siyasi partiler için televizyonun yeri ayrıdır. Çünkü televizyon Doğan ve Aslantaş'ın ifade ettiğine göre $(2015,39)$ eğlence ve bilgi kaynağı olması bakımından diğer kitle iletişim araçları arasından öne çıkmaktadır. Siyasi partiler siyasal reklamlarını seçmenle buluşturmada televizyondan faydalanmaktadırlar. Siyasal ortamın izlenilmesini kolaylaştıran ve siyasal bilginin kaynağı olarak geniş kitlelerce seyredilen televizyon, bu ortamda yayınlanan siyasal reklamları seçmenlere ulaştırmanın aracı konumundadır. Siyasi partilerin dikkat çekmeye çalıştığı noktalar televizyonda yayınlanan siyasal reklamlar aracılığı ile daha etkili hale getirilmektedir. Böylece siyasi mesajlarını seçmenlere ulaştırmak isteyen siyasi partiler televizyon vasıtasıyla bu mesajları daha geniş kitlelere ulaştırmaktadır. Bostancı $(2010,151)$ görme duyusuna hitap etmesiyle birlikte televizyonun yalnızca siyasi mesajları iletmekle kalmayıp siyasetçilerin dış görünüşleri ve beden dili hakkında da seçmenlere fikir verdiğini ifade etmektedir. Bu da siyasi aday ya da parti imajı oluşum sürecinde etkili bir araç olabileceğinin göstergesidir.

Bu araştırmada 24 Haziran 2018 Genel Seçimlerinde Ak Parti, CHP ve MHP'nin televizyonda yayınlanan siyasal reklamları değerlendirilmiştir. İçerik çözümleme yönteminin kullanıldığı bu araştırmada siyasi partilerin reklam süreleri, kullanılan reklam türü, çekicilik, lider görüntüsü, reklamdaki baskın ses ve reklamın ele aldığı konular değerlendirilmiş ve partiler arası farklılıklar ortaya konulmaya çalışılmıştır.

\section{Siyasal Reklam}

Seçmenlere en etkili yoldan kısa sürede mesajlarını iletmek isteyen siyasal partiler, bunun için çeşitli stratejiler ve taktikler geliştirirler. Bu taktikler arasından özellikle siyasal reklamlar daha kısa yoldan seçmenle buluşabilmenin anahtarı olarak ifade edilebilir. Kaid $(2008,558)$ siyasal reklamcılık faaliyetlerini aday, parti, birey ve grupların kitle iletişim araçları vasıtasıyla kendilerini tanıtma amacıyla kullandıkları bir yöntem olarak tanımlamaktadır.

Bir başka tanımda ise siyasal reklam, aday ya da siyasi partinin medyadan yer ve zaman satın alması neticesinde seçmenlerin tutum ve davranışlarını aday ya da parti lehine çevirmek amacıyla yapılan siyasal iletişim kampanyası (Uztuğ, 2004, 315) olarak ifade edilmektedir. Diğer reklamcılık alanlarında olduğu gibi siyasal reklamcılık alanı da çeşitli kitle iletişim araçlarını kullanarak siyasi parti ve adaylara yönelik olumlu duygular geliştirmek amacını güden bir iletişim türüdür (Lilleker, 
2013, 201). Bu iletişim türü sayesinde siyasal partiler ya da adaylar hazırlanan reklam filmleriyle iletmek istediklerini daha geniş kitlelere hitap edebilen kitle iletişim araçlarıyla ulaştırabilmektedirler. Kısaca belirtmek gerekirse kitle iletişim araçları yoluyla yayınlanan siyasal reklamlar, siyasi partiler ya da adaylar için yalnızca bir fikrin satılması işlevini yerine getirmezler, aynı zamanda seçmenlerin bilgilendirilmesine ve olumlu bir imaj olușturulmasına da katkı sağlarlar.

İkna edici bir iletişim biçimi olan siyasal reklamların farklı amaçlar bulunmaktadır. Siyasi reklamlar, siyasi partilerin hedef kitlelerini harekete geçirecek nitelikte olmasının yanı sıra kısa, basit ve anlaşılır olmalıdır. Seçim döneminin niteliklerine göre şekillenebilen siyasal reklamların bu doğrultuda farklı amaçları bulunmaktadır. Siyasal reklamların amaçları aşağıdaki gibi örneklendirilebilir (Uztuğ, 2004, 316-317):

- Yeni bir aday/partinin seçmenlere tanıtılması,

- Kampanya gündemini oluşturma ve yönlendirme,

- Seçmen tutumlarını değiştirme.

Reklamcılık ve propaganda faaliyetlerinin beraberliği neticesinde ortaya çıkan siyasal reklamlar, seçim dönemlerinde siyasi çevreler tarafından sıklıkla başvurulan bir yöntemdir. Seçmenlere ulaşabilmek maksadıyla reklam mecralarında kendi fikir, vaat ve diğerlerinden farklılıklarını anlatmaya aracı olarak kullanılan siyasal reklamlar, seçmenler üzerinde önemli bir etkiye sahiptirler (Doğan ve Göker, 2013, 88). Bütçe ve süre sınırlaması olmaksızın her türlü siyasal reklam, iktidar sahibi olmak isteyen siyasetçilerin gözdesi konumundadır (Devran, 2004, 15). Bu konumda olmasının sebebi ise siyasi partilerin ve adayların hedef kitleye ulaşma konusunda zorluklar yaşamalarına bağlanabilir. Bu zorluğun başlıca nedenleri arasında birbirine benzeyen parti programları gösterilebilir. Farklılaşma yolunu seçen siyasi partiler, mesajlarını daha düzenli ve planlı hale getirerek siyasal reklam uygulamalarına yönelmişlerdir (Zeybek, 2016, 64). Böylece siyasal reklam uygulamalarına olan ilgi artmış ve profesyonel anlamda siyasal reklamcılık faaliyetleri yürütülmeye başlanmıștır. Bunun neticesinde ise her seçim döneminde daha da profesyonelleşmiş reklam kampanyaları karşımıza çıkmaktadır. Siyasi partiler seçimlere az bir süre kala en etkili reklam filmlerini seçmen kitlelere ulaştırarak karar sürecini etkilemeyi hedeflemektedirler. Siyasi partiler bunun için çeşitli kitle iletişim araçlarından yararlanmaktadırlar.

\section{Televizyonda Siyasal Reklamlar}

Siyasi partiler hedef kitlelere siyasal reklamlarını ulaştırmada çeşitli kitle iletişim araçlarından yararlanmaktadırlar. Bu kitle iletişim araçları içinde televizyon-sinema, radyo, gazete-dergi, açık hava ve internet gibi araçlar bulunmaktadır. Uztuğ (1999, 122) tecimsel reklam kampanyalarının kitle iletişim araçlarından faydalanırken bütüncül bir yaklaşım benimsediğini ifade etmektedir. Siyasal mesajların aktarımında çeşitli kitle iletişim araçları kullanılsa da, bu araçlar arasından televizyonun -her ne kadar internetin yaygınlaşması ve kolay erişilebilir olması söz konusu olsa da- çok geniş kitlelere erişebilmesi siyasal reklamların yayınlanması onu en çok tercih edilen mecralardan biri haline getirmiştir. Televizyonun göze ve kulağa hitap edebilen bir araç olması, ayrıca kullanabilmek için hiçbir eğitim gerektirmemesi oldukça önemlidir. Böylece televizyon çok çeşitli seçmen kitlesine hitap edebilmektedir. 
Televizyon birbirinden çok farklı özelliklere sahip seçmenlere siyasal mesajların ulaştırılmasında önemli roller üstlenirken; diğer taraftan toplumun farklı kesimlerinin sesini duyurmada sağladığı imkânlar nedeniyle de dikkate alınması gereken bir araçtır (Balcı ve diğerleri, 2013, 86). Televizyonun diğer kitle iletişim araçlarına göre daha fazla tercih edilebilir olmasının sebebini Çankaya (2015, 53-54) yüksek ikna gücüne bağlar. Televizyonun ardından ise ona en yakın ikna gücüne sahip olarak yazılı basını işaret etmektedir. Aydemir $(2016,178)$ ise televizyonun gücünü uydu teknolojisi sayesinde dünyanın her yerinde izleyiciyle kolayca buluşabilmesine bağlar. Böylece seçim kampanyaları boyunca siyasal partiler ve adaylar televizyonda yayınlanan siyasal reklamların yanı sıra açık oturumlar, tartışma programları vb. gibi etkinliklere dâhil olarak televizyonun gücünden faydalanmaktadırlar. Aziz $(2011,125)$ televizyonda yer alan siyasal reklamların siyasi partilere iki șekilde faydalı olduğunu ifade etmektedir. Bunlardan ilki televizyondan zaman satın alınarak siyasal reklam filminin yayınlatılması şeklindeyken; diğeri ise televizyonda yayınlanan programların satın alınması şeklindedir. İnsanların televizyon izleme motivasyonlarının ortaya konulduğu bir araștırmada; eğlence, heyecan ve arkadaşlarla etkileşim amaçlı bilgi edinme ve siyasal ortamı izleme isteği gibi sonuçlara ulaşılmaktadır (Uztuğ, 2004, 323). $\mathrm{Bu}$ nedenledir ki televizyon, hedef kitlelerin evlerine siyasal hayatın taşıyıcısı vazifesini üstlenir. Balcı ve Bekiroğlu $(2012,269)$ Batı'da yapılan birçok araştırma sonucunun televizyon üzerinden yayınlanan siyasal reklamların, seçmenlerin karar oluşturma süreçlerine yardımcı olduğunu ifade etmektedirler.

Siyasal reklamların tarihine bakıldığında ilk siyasal televizyon reklamının Einsenhower'ın 1952 yılında yaptığı ve Amerika'da geniş yankı uyandıran reklam filmi olduğu görülmektedir (Lilleker, 2013, 201). Ülkemizde ise 2011 genel seçimleriyle siyasal reklamların televizyondan yayınlanmasının yolunun açılması siyasi partiler için önemli bir gelişmedir. Siyasal bilgi kaynağı olan televizyon siyasal reklamların yayınlanmasına da aracılık ederek siyasal kampanya sürecinin önemli bileşenlerinden birisi konumuna gelmiştir (Doğan ve Aslantaş, 2015, 36). Tüm bu gelişmeler siyasal reklamlardan faydalanmayı sürekli hale getirerek siyasal reklamlara ayrılan bütçenin her geçen yıl artarak devam etmesini sağlamıştır. Böylece televizyonda yayınlanan siyasal reklamlar, seçim kampanyalarının en önemli unsuru haline gelmiştir. Özellikle son seçim dönemlerinde televizyonda yayınlanan siyasal reklamların teknik ve diğer açılardan ilerlemesi göz önüne alındığında, televizyonun ve bu araç üzerinden yayınlanan mesajların seçmenler üzerinde etkili olduğu sonucu yadsınamaz bir gerçekliktir. Siyasi parti ve adayların büyük bütçeler ayırarak bu siyasal iletişim yönteminden yararlanmak istemesi de bunu doğrular niteliktedir. Bekiroğlu ve Bal $(2014,132)$ ise farklı çekim teknikleri ve özel aydınlatmalar kullanılarak kurgulanan siyasal reklamların seçmenlerin ilgisini çekebilmek adına müzik, efekt ve animasyonlara da yer verdiğini ve bunun bir maliyet gerektirdiğini ifade etmektedirler. Prodüksiyon maliyetinin yanında pahalı bir mecra olan televizyonda siyasal reklamın yayınlatılmasının yüksek bütçeler gerektirmesi bir sorun olarak belirmekte ve finansal açıdan sorun yaşayan partilerin siyasal reklamlarının televizyonda yer almaması sebebiyle bu aracın dar bir yapının kontrolünde olabileceğini hatırlatmaktadır.

Balcı (2016, 288) siyasal reklamın etkisinin ancak oy verme davranışı ile ölçülebildiğinin altını çizmektedir. Her ne kadar televizyon reklamları daha geniş 
kitlelerin aday ya da siyasi partiyi tanımasına ve olumlu bir izlenim oluşturmasına imkân verse de bu seçmenin oy verme davranışı neticesinde açıklığa kavuşacak bir mevzudur. Nitekim televizyon reklamları daha karar almamış ve kampanya sürecinde karar verecek olan seçmenin karar alma sürecini etkileyebilmektedir.

Uztuğ (2004, 318-319) siyasal reklamların mesaj içeriğini şu şekilde siniflandirmaktadır:

- Parti konumunu ve kimliğini vurgulayan reklamlar,

- Lider imajını geliştirmeyi hedefleyen reklamlar,

- Adayların partililik bağını, partiye olan bağlılığını vurgulayan reklamlar,

- Adayların sahip oldukları özellikleri işleyen, kişisel özelliklerini ya da devlet deneyimlerini, başarılarını öne çıkaran reklamlar,

- İktidarın kendi icraatlarını öven, vurgulayan ya da muhalefetaçısından iktidarın icraatlarını yeren, küçümseyen reklamlar,

- Özel toplumsal katmanları ya da demografik grupları hedef alan reklamlar,

Televizyonda yayınlanan siyasal reklamlar içerikleri ve amaçlarına göre farklılıklar gösterirken; siyasal adaylar tarafından kullanılan destekleme, kıyaslama ve olumsuzlama (negatif) şeklinde üç tip reklamcılığın mevcut olduğu görülmektedir (Lilleker, 2013, 201). Televizyon reklamlarının pozitif ya da negatif içeriğe sahip olması dikkatleri çeken bir konu olmuştur. İcraatları ve gelecekteki uygulamalara yönelik bilgileri aktaran ve olumlu imaj oluşturmaya yarayan reklamların yanı sıra rakiplerin yetersizliklerine doğrudan ya da ima yoluyla vurgu yapan reklamlar mevcuttur (Balcı, 2016, 290). Dolayısıyla pozitif siyasal reklam siyasi parti ya da liderinin övülmesi, geçmişte yaptıklarını gelecekte de yapacağı hususunda güvence verilmesine dayanır.

Negatif siyasal reklam ise partiye ya da örgüte olumsuz siyasal mesajları gönderme, karşı tarafı kötüleme ve ulaşılmak istenen hedef kitlede kafa karışıklığına sebep olarak onları yüzer gezer seçmen kitlesine dâhil edebilmek için çalışmaktadır (Kılıçaslan, 2013, 54). Negatif içerikli reklamlar insanlar tarafından sevilmese de hatırlanma oranı oldukça yüksektir (Bekiroğlu ve Bal, 2014, 110). Nitekim negatif içerikli reklamlarda rakip aday ve onun başarısızlıkları sürekli dile getirilmektedir (Devran, 2003, 140). Negatif içerikli reklamların doğrudan saldırı reklamı, doğrudan karşılaştırmalı reklam ve imalı karşılaştırma reklamı şeklinde türlere ayrıldığı görülmektedir. Doğrudan saldırı reklamlarında aday ya da siyasi partiler birbirleri ile kıyaslanmaz. Bu reklam türünde doğrudan rakibe saldırı içeren mesajlar mevcuttur. Doğrudan karşılaştırma reklamlarında ise rakiplerin birbiri ile olan farkları ortaya koyularak, üstün ya da zayıf noktaları seçmenlerin önüne konmaktadır. İmalı karşılaştırma reklamlarında ise parti ya da aday kendisi ile ilgili her şeyi hedef kitlelere iletip rakiple ilgili herhangi bir eleştiride bulunmaz. Seçmenden "müzakereli bir okuma" sürecini geçekleştirmesi beklenmektedir. Çağrışım yapacak ipuçları vererek üstü kapalı şekilde kamuoyundan karşılaştırma yapması talep edilmektedir (Bekiroğlu ve Bal, 2014, 118-123). Siyasi partilerin pozitif içerikleri genellikle imaj reklamlarında kullandıkları gözlemlenirken; negatif içerikli reklamları ise karşıdaki aday ya da siyasi partiyi kötülemek ve oy kaybına uğratmak maksadıyla kullandıkları karşılan bir durumdur. 


\section{Yöntem}

$\mathrm{Bu}$ araştırmada yöntem olarak içerik çözümlenmesi kullanılmıştır. İçerik çözümlemesi ile ilgili Berelson'un yaptığı tanım şu şekildedir: "içerik çözümlemesi, iletişimin belirgin yazılı/açık içeriğinin objektif, sistematik ve niceliksel tanımlarını yapan bir araştırma tekniğidir" (Gökçe, 2001, 7). Krippendorff $(1980,18)$, içerik çözümleme yöntemini metinlere ve kullandıkları bağlamlara yönelik anlamlı, tekrarlanabilir ve geçerli çıkarımlar yapmak için faydalanılan bir araştırma tekniği olarak tanımlamaktadır. İçerik çözümleme yöntemi ile kavramların ve değişkenlerin ölçümlenebilmesiveanlam çıkarılabilmesimümkündür. Bununiçinkategorilendirme işlemine de yer verilmektedir. Bu çalışmada hem pozitif ve negatif reklamları hem de konu reklamları ve imaj reklamları şeklinde iki ayrı sınıflandırmaya yer verilmiștir. Yine negatif reklamlar değerlendirilirken doğrudan saldırı, doğrudan karşılaştırma ve imalı karşılaştırma şeklinde başlıklandırılmıştır. Çalışmada çekicilik türleri ele alınırken rasyonel ve duygusal çekicilik şeklinde sınıflandırılmıştır. Yine çalışmada lider görüntüsü var/yok şeklinde ele alınırken; reklamda baskın olan ses lider sesi, sunucu sesi, halkın sesi ve birden çok ses şeklinde ele alınmıștır.

24 Haziran 2018 Cumhurbaşkanlığı ve Milletvekili Seçimleri'nde Ak Parti, CHP ve MHP'nin ulusal televizyonlarda yayınlanan ve Youtube üzerinde arşivlenen 19 farklı siyasal reklam değerlendirilmiştir. Ak Parti'nin yayınladığı reklam filmlerinin isimleri ise şöyledir: "24 Haziran'da güzel bir başlangıç yaptık, geçmişi unutmayalım, Türkiye vakti, Zümrüdüanka, rehber tuttum yüreğime, biz birlikte güçlüyüz (elini uzat), biz birlikte güçlüyüz (vakit geleceğe el ele yürüme vakti), biz çalıştıkça konuşacaklar yıkılmadan dimdik duracağız, biz Ege'den Karadeniz'e Doğu'dan Marmara'ya birlikte güçlüyüz, aktır bizim davamız ay yıldız gibi. MHP'nin televizyonda yayınlanan reklam filmlerinin isimleri; davet, 15 Temmuz, ülkemiz için her şeye değer iken; CHP'nin reklam filmlerinin isimleri ise şu şekildedir: Millet için geliyoruz (engelliler), millet için geliyoruz (genel), eğitim, yürüyoruz, millet için geliyoruz (Türkiye gerçek gücüne kavuşacak), millet için geliyoruz (Türkiye'nin önünde önemli sorunları var). Bu çalışma 24 Haziran seçimleri ve Ak Parti, CHP ve MHP'nin televizyonlarda yayınlanan 19 farklı reklamları ile sınırlandırılmıştır. Oluşturulan kodlama cetvelinin hazırlanmasında Balcı ve Bekiroğlu'nun (2014, 152-153) çalışmalarında kullandığı kodlama cetvelinden ve araştırma sorularından yararlanılmıştır:

Bu amaçla araştırmada şu sorulara yanıtlar aranmaya çalıșılmıştır.

1. Partilerin (Ak Parti, CHP, MHP) reklam süreleri arasında farklılıklar var mıdır?

2. Partilerin (Ak Parti, CHP, MHP) kullandıkları negatif siyasal reklam türünde farklılık var mıdır?

3. Partilerin (Ak Parti, CHP, MHP) kullandıkları reklam çekicilik türünde farklılıklar var mıdır?

4. Partiler (Ak Parti, CHP, MHP) reklamlarında hangi konulara ağırlık vermişlerdir?

5. Partiler (Ak Parti, CHP, MHP) televizyondaki siyasal reklamlarında hangi sesi daha çok kullanmışlardır?

6. Partiler (Ak Parti, CHP, MHP) televizyondaki siyasal reklamlarında lider görüntüsüne ne oranda yer vermişlerdir?

7. Partiler televizyondaki siyasal reklamlarında hangi mesaj stratejisi ve taktiğine ağırlık vermişlerdir? 


\section{Bulgular}

Araştırmanın bu kısmında 24 Haziran seçimlerinde Ak Parti, CHP ve MHP'nin siyasal reklamları irdelenmiştir. Seçim döneminde yayınlanan siyasi parti reklamlarının süresi, reklam türündeki farklılıklar, kullandıkları negatif reklam türleri, reklam çekicilikleri, reklamlardaki baskın ses, lider görüntüsü kullanımı ve reklamlarda işlenen konu itibari ile karşılaștırılmış ve aşağıda tablolar halinde sunulmuştur.

Tablo 1: 24 Haziran Genel Seçim Döneminde Partilerin TV Reklam Sürelerinin Farklılığı

\begin{tabular}{|c|c|c|c|}
\hline & \multicolumn{3}{|c|}{ PARTILER } \\
\hline \multirow{2}{*}{$\begin{array}{l}\text { Yayınlanan Reklam } \\
\text { Sayısı ve Süresi }\end{array}$} & $\begin{array}{c}\text { Ak Parti } \\
\text { (sayı ve dakika) }\end{array}$ & $\begin{array}{c}\text { CHP } \\
\text { (sayı ve dakika) }\end{array}$ & $\begin{array}{c}\text { MHP } \\
\text { (sayı ve dakika) }\end{array}$ \\
\hline & 10 / 1 saat 13 dk. 59 sn. & 6 / 2 dk. 57 sn. 17 sl. & $3 / 2 \mathrm{dk} .5 \mathrm{sn}$. \\
\hline
\end{tabular}

24 Haziran Genel seçimlerinde Ak Parti, CHP ve MHP'nin TV'de yayınlanan reklam süreleri birbirinden farklılık göstermektedir. Ak Parti (10), CHP (6) ve MHP (3)'nin TV'de yayınlanan reklam filmleri ele alınarak reklam sürelerinin farklılıkları ortaya konulmuştur. Tablodan elde edilen verilere göre siyasi partilerin TV reklam süreleri değerlendirildiğinde Ak Parti'nin sayıca daha fazla reklam filmi yayınladığı ve reklam sürelerini uzun tuttuğu görülmektedir. Bunu sırasıyla CHP ve MHP takip etmektedir. Yayınlanan reklam filmi sayılarının ve sürelerinin birbirinden farklı olması siyasi partilerin seçim kampanyalarında kullandıkları bütçelerin eşit miktarlarda paylaştırılmıyor olmaları ile ilişkilendirilebilir.

Tablo 2: 24 Haziran Seçimlerinde Partilerin Kullandığı Reklam Türündeki Farklılık

\begin{tabular}{|l|c|c|}
\hline PARTiLER & Pozitif Reklam & Negatif Reklam \\
\hline Ak Parti & 8 & 2 \\
\hline CHP & 3 & 3 \\
\hline MHP & 3 & - \\
\hline
\end{tabular}

24 Haziran Genel seçimlerinde Ak Parti ve MHP'nin siyasi reklam türleri bakımından bu seçim dönemi içinde genellikle pozitif içerikli reklamlardan faydalandıkları ifade edilebilir. Özellikle Ak Parti reklamlarında lider odaklı ve birlik ve beraberlik algısını pekiştiren pozitif içerikli reklamlar hazırlamaya özen göstermiştir. CHP'nin ise bu seçim dönemi içindeki siyasi reklamları değerlendirildiğinde pozitif ve negatif içerikli reklamlardan eşit şekilde faydalandığı görülmüştür.

Tablo 3: 24 Haziran Seçimlerinde Partilerin Kullandığı Negatif Reklam Türündeki Farklılıklar

\begin{tabular}{|l|c|c|}
\hline \multicolumn{3}{|c|}{ Negatif Siyasal Reklam Türü } \\
\hline Partiler & Doğrudan Saldırı & İmalı Karşılaştırma \\
\hline Ak Parti & 1 & 1 \\
\hline CHP & 2 & 1 \\
\hline MHP & - & - \\
\hline
\end{tabular}

24 Haziran seçimlerinde negatif reklam türlerinin kullanımı siyasi partilere göre farklılık göstermektedir. CHP’nin negatif reklam türleri içinde doğrudan saldırı türünde reklamları daha fazla kullandığı ifade edilebilir. Böylece bu seçim döneminde doğrudan saldırı ve imalı karşılaştırma türleri Ak Parti ve CHP tarafından kullanılmış olup, iktidar ve ana muhalefet partisinin mücadelesi reklamlara da yansımıştır. Ak Parti geçmişte dini inanç ve uygulamalara getirilen 
yasakların hatırlatılmasını doğrudan saldırı șeklinde kullanırken; CHP mevcut durumun eleştirisini yapmaktadır. MHP ise siyasal reklamlarında negatif reklam türlerine yer vermemiştir. Ak Parti genellikle negatif reklam türlerinde geçmişte yaşanan olayları hatırlatmayı tercih ederken; CHP şu anki gidişatı eleştiren ve mevcut durumun onaylamadığını negatif reklam türleriyle ortaya koymuştur. Reklamların geneli değerlendirildiğinde ise negatif reklam türü içinde yer alan doğrudan karşılaştırmalı reklamlara yer verilmediği gözlemlenmiştir.

Tablo 4: 24 Haziran Seçimlerinde Partilerin Kullandığı Reklam Çekiciliklerindeki Farklılık

\begin{tabular}{|l|c|c|}
\hline \multicolumn{3}{|c|}{ Reklam Çekicilikleri } \\
\hline Partiler & Rasyonel Çekicilik & Duygusal Çekicilik \\
\hline Ak Parti & 2 & 8 \\
\hline CHP & 4 & 2 \\
\hline MHP & - & 3 \\
\hline
\end{tabular}

Ak Parti ve MHP'nin siyasi reklamlarında genellikle duygusal çekicilikten yararlandıkları ve reklamlarındaki temel konun milli birlik ve beraberlik olduğu ifade edilebilir. 15 Temmuz sonrasında yaşanan ülkedeki birlik ve beraberlik havası Ak Parti ve MHP'nin reklamlarına yansımıștır. Bunun yanı sıra Ak Parti reklamlarında rasyonel çekicilikten de faydalanmıştır. CHP ise bu seçim dönemi içinde ağırlıklı olarak rasyonel çekicilikten yararlanmayı tercih etmiştir. Ancak yine reklamlarında duygusal çekicilikten yararlanmayı da ihmal etmemiştir.

Tablo 5: 24 Haziran Seçimlerinde Partilerin Kullandığı Baskın Sesteki Farklılık

\begin{tabular}{|l|c|c|c|c|}
\hline \multicolumn{5}{|c|}{ Siyasi Partilerin Reklamlarında Baskın Olan Ses } \\
\hline Partiler & Sunucu Sesi & Halkın Sesi & Lider Sesi & Karışık Ses \\
\hline Ak Parti & 1 & 3 & 2 & 4 \\
\hline CHP & 5 & - & - & 1 \\
\hline MHP & 1 & - & 1 & 1 \\
\hline
\end{tabular}

24 Haziran seçimlerinde siyasi partilerin reklamlarında kullanılan baskın ses farklılık göstermektedir. CHP siyasal reklamlarında sunucu sesini baskın ses olarak kullanmaktadır. Ak Parti ise daha çok halkın sesi ve liderin sesinin bir arada bulunduğu karışık ses kullanmaktadır. Hem liderin hem de halkın sesi Ak Parti reklamlarında bir arada duyulmaktadır. MHP'nin siyasal reklam filmlerinde kullandığı baskın ses değerlendirildiğinde ise sunucunun, liderin ve karışık sesin eşit kullanıldığı görülmektedir.

Tablo 6: 24 Haziran Seçimlerinde Partilerin Reklamlarında Lider Görüntüsü Kullanımı

\begin{tabular}{|l|c|c|}
\hline \multicolumn{3}{|c|}{ Lider Görüntüsü Kullanımı } \\
\hline Partiler & Var & Yok \\
\hline Ak Parti & 10 & - \\
\hline CHP & 2 & 4 \\
\hline MHP & 3 & - \\
\hline
\end{tabular}

24 Haziran seçim dönemi içinde siyasal reklamlarda lider kullanımına en çok yer veren siyasi parti Ak Parti olmuştur. Televizyon reklamlarında lider kullanımında Ak Parti'yi sırasıyla MHP ve CHP izlemektedir. Siyasi partiler için siyasal reklamlar aynı zamanda imaj oluşturma işlevini yerine getirmektedir. Siyasi parti liderlerin görüntülerine de sıklıkla yer verildiği göze çarpmaktadır. Ak Parti'nin siyasal reklamlarında lider görüntüsüne yer vermesi siyasi parti liderinin aynı zamanda cumhurbaşkanı adayı olması ile açıklanabilir. 
Tablo 7: 24 Haziran Seçimlerinde Partilerin Reklam Konularındaki Farklılık

\begin{tabular}{|l|c|c|c|}
\hline \multirow{2}{*}{ KONULAR } & \multicolumn{3}{|c|}{ PARTiLER } \\
\cline { 2 - 4 } & Ak Parti & CHP & MHP \\
\hline Eğitim & - & 1 & - \\
\hline Engelliler & - & 1 & - \\
\hline Birden çok konu (Ekonomi, işsizlik, çiftçi, güvenlik, tarım vb.) & - & 4 & - \\
\hline Milli birlik ve beraberlik & 9 & - & 3 \\
\hline Dini inanç özgürlüğü & 1 & - & - \\
\hline
\end{tabular}

Tablo 7'e göre bu seçim döneminin Ak Parti ve MHP tarafından en fazla üzerinde durulan konu milli birlik ve beraberlik olmuştur. Özellikle siyasal reklamlarında birlik ve beraberliğin önemine vurgu yapan bu partiler, reklam filmlerinde diğer konulara yer vermemişlerdir. CHP ise bu seçim dönemi içinde hazırladığ siyasal reklam filmlerinde birden fazla konuyu ele almıştır. Bu konuların yanı sıra eğitim ve engelliler ile ilgili reklam içerikleri hazırlayarak bu konulara dikkat çekmeye çalışmıştır.

\section{Sonuç}

24 Haziran 2018 hem cumhurbaşkanlığı hem de milletvekilliği seçim sürecinin birlikte yürütüldüğü bir dönem olmuştur. Ak Parti, CHP ve MHP bu erken seçim döneminde siyasal reklamlarında farklı kampanyalar ve mesaj stratejileri ile seçmenleri ikna etmeye çalışmışlardır. Ülkenin içinde bulunduğu zorlu koşullar dikkate alındığında erken seçimlerin yapılması siyasi partilere seçim yarışına hazırlanmaları için kısıtlı bir zaman dilimi sunmuştur.

$\mathrm{Bu}$ seçim dönemi içinde yapılan siyasal reklamlarda hemen hemen bütün siyasi partilerin kullandıkları tema milli birlik ve beraberlik üzerinedir. Özellikle Ak Parti ve MHP siyasal reklamlarını bu tema üzerine şekillendirmiştir. Ülke içinde ve ülke sınırlarına yakın noktalarda yaşanan güvenlik mücadeleleri milli birlik ve beraberlik söylemlerini pekiştirmiştir. 15 Temmuz darbe kalkışması sonrasında siyasi parti liderlerinin yakınlaşmaları ile de "YeniKapı Ruhu" oluşmuştur. Cumhurbaşkanlığı tarafından düzenlenen "Demokrasi ve Şehitler Mitingi”ne katılan Ak Parti, CHP ve MHP'nin genel başkanları birlik ve beraberlik mesajı vermişlerdir. Bu birliktelik ortamı partiler arası iş birliğinin de önünü açmıştır. Nitekim siyasi partiler bu seçimlere kendi aralarında kurdukları ittifaklar ile dâhil olmuşlardır. Ak Parti ve MHP Cumhur ittifakı; CHP, İyi Parti, Saadet Partisi ve Demokrat Parti de Millet İttifakı altında toplanmışlardır.

Yenikapı'dan sonra Ak Parti ve MHP arasındaki dayanışmanın derinleşerek devam etmesi daha önceki seçim döneminde iki parti arasında yaşanan rekabet durumunun yerini milli menfaatler için bir araya gelme durumuna bırakmıştır. Bu nedenle de daha önceki seçim dönemlerinden farklı olarak her iki siyasi partinin keskin görüş ayrılıklarının ortadan kalkması ile süreç neticelendirilmiştir. Böylece Ak Parti ve MHP'nin siyasi dayanışma içinde olması, negatif içerikli reklam kampanyalarından kaçındıkları ve milli birlik ve beraberlik temasının hâkim olduğu reklam kampanyalarına yer verdikleri gözlemlenmektedir. Dahası televizyonda yayınlanan reklam filmlerinde milletin 15 Temmuz da meydanlarda bulunmasını anımsatan görüntülere de sıklıkla yer verilmektedir. $\mathrm{Bu}$ tema doğrultusunda milletin hassas olduğu noktalar dikkatlice ele alınarak siyasi reklamların daha etkili olması adına ülke ve milli değerler ön planda tutulma koşuluyla, duygusal çekiciliğe yer veren 
reklamların tüm partiler tarafından daha fazla kullanıldığı gözlemlenmektedir. Ak Parti'nin genellikle siyasal reklamlarında pozitif reklam içeriklerini sıklıkla kullandığı; negatif reklam içeriklerine ise çok fazla yer vermediği ifade edilebilir. Tam da hassas dönemlerin sonunda seçim dönemine girilmesi seçmen kitlenin önceliklerinin ve duygusallaştığı noktaların ortak olması siyasi partilerin mesaj stratejilerinin belirleyicisi olmuştur.

Ak Parti Recep Tayyip Erdoğan'ın şiir okuduğu ve seçmene seslendiği görüntülere reklam filmlerinde sıkça yer vermiştir. CHP'nin reklam filmleri değerlendirildiğinde ise hem negatif hem de pozitif reklam içeriklerini eşit kullandığı göze çarpmaktadır. Seçim dönemine girilmesiyle beraber -15 Temmuz döneminde yaşanan birliktelik ortamının aksine-Ak Parti ve CHP yeniden rakip partiler haline gelmiștir. Bu sebeple CHP negatif içerikli reklamlarında özellikle de mevcut siyasi iktidara doğrudan saldırı reklamları ile dikkat çekmektedir. CHP'nin siyasal reklamlarında işlediği konular değerlendirildiğinde ise ekonomi, eğitim, engelliler, özgürlük vb. gibi birden fazla konuya temas ettiği ve bu konular üzerinden negatif içerikli reklamlar ürettiği ifade edilebilir. Lider görüntüsü ve sesinin kullanımı çok olmamakla birlikte CCHP'nin siyasal reklam filmlerinde de yer almaktadır. MHP ise siyasal reklamlarında genellikle pozitif içerikler kullanırken, milli birlik ve beraberlik vurgusu yapmıştır. Siyasal reklamlarında baskın ses olarak Devlet Bahçeli'nin de seçmene seslendiği bir reklam filmi hazırlatmıştır.

Nitekim siyasi partilerin, her seçim döneminde olduğu gibi ülkenin gündemi ile ilintili konulara yer verdikleri ve siyasal reklamlarını seçmenlerle buluşturdukları ifade edilebilir. Hem vaatlerini anlattıkları hem de rakiplerini eleştirdikleri reklamların görüntü kalitesi, ses ve teknik donanımlar itibari ile ilgili bir değerlendirilmesi yapıldığında bu alandaki kaydedilen mesafe göze çarpmaktadır. Büyük bütçeler ayrılarak çekimleri yapılan reklam filmlerinin konuları, görsellik ve seslendirilmeleri itibari ile büyük yankılar uyandırdığı ayrıca reklam filmlerinin gösterildiği zaman dilimi dışında da etkileyici olması ile pek çok ana haber bülteni ve köşe yazısına konu olduğu gözlemlenmektedir.

\section{Kaynakça}

Aydemir, E. (2016). Dış Politikada Yumuşak Güç ve Medya. İstanbul: Kalkedon Yayınları.

Aziz, A. (2011). Siyasal İletişim. Ankara: Nobel.

Balcı, Ş. ve Bekiroğlu, O. (2012). İçerikten Anlama Giden Bir Tünel Olarak İçerik Çözümlemesi: 2011 Genel Seçimlerinde Ak Parti TV Reklamları Üzerine Bir Araştırma. Özlem Güllüoğlu (Ed.) İletişim Bilimlerinde Araştırma Yöntemleri: Görsel Metin Çözümleme (s. 268-323). Ankara: Ütopya Yayınevi.

Balcı, Ş. Tarhan, A. ve Bal, E. (2013). Medya ve Siyasal Katılım. Konya: Literatürk Akademi.

Balcı, Ş. (2016). 7 Haziran'dan 1 Kasım'a Türkiye'de Televizyonda Siyasal Reklam Uygulamaları: "Partilerin Mesaj Stratejileri ve Taktikleri”. Şükrü Balcı (Ed.) 7 Haziran'dan 1 Kasım'a Türkiye'de Siyasal İletişim Uygulamaları (s. 281-347). İstanbul: Literatürk Academia Yayınları, 281-347.

Bekiroğlu, O. ve Bal, E. (2014). Siyasal Reklamcılık. İstanbul: Literatürk. 
Bostancı, M. N. (2010). Siyaset ve Medya-Alacakaranlığın İki Atlısı. İstanbul: Özgür Yayınları.

Çankaya, E. (2015). Siyasal İletişim: Dünya'da ve Türkiye'de. Ankara: İmge.

Devran, Y. (2003). Siyasal Kampanya Yönetimi: Mesaj, Strateji ve Taktikler. İstanbul: And Yayınları.

Devran, Y. (2004). Siyasal Kampanya Yönetimi. (2. Baskı). İstanbul: Odak İletişim.

Doğan, A. ve Aslantaş, A. G. (2015). Bir İkna Yöntemi Olarak Siyasal Reklamlarda Millet ve Hizmetin Temsili. Akademik Bakış Uluslararası Hakemli Sosyal Bilimler Dergisi, (47), 35-52.

Doğan, A. ve Göker, G. (2013). Siyasal İletişim Araştırmaları. Ankara: Nobel Yayınları.

Gökçe, O. (2001). İçerik Çözümlemesi: Teori-Metod-Uygulama. Konya: Selçuk Üniversitesi Vakfl.

Kaid, L. L. (2008). Political Advertising. Kaid, L. L., and Holtz-Bacha, C. (Eds.). Encyclopedia of political communication (s. 558-565). London, UK: Sage.

Kılıçaslan, E. Ç. (2013). Siyasal İletişim İdeoloji ve Medya İlişkisi. Edirne: Paradigma Akademi.

Krippendorf, K. (1980). Content Analysis: An Introduction to Its Methodology. New York: Sage Publication.

Lilleker, D. G. (2013). Siyasal İletişim: Temel Kavramlar. İstanbul: Kaknüs Yayınları.

Uztuğ, F. (1999). Siyasal Marka Seçim Kampanyaları ve Aday İmajı. İstanbul: Mediacat Kitapları.

Uztuğ, F. (2004). Siyasal İletişim Yönetimi: Siyasette Marka Yaratmak. İstanbul: Mediacat Kitapları.

Zeybek, B. (2016). Siyasal Reklam İkna ve Retorik. İstanbul: Beta. 